\title{
Ungulate browsing on European silver fir Abies alba: the role of occasions, food shortage and diet preferences
}

Author(s): Helene Häsler \& Josef Senn

Source: Wildlife Biology, 18(1):67-74.

Published By: Nordic Board for Wildlife Research

DOI: http://dx.doi.org/10.2981/09-013

URL: http://www.bioone.org/doi/full/10.2981/09-013

BioOne (www.bioone.org) is a nonprofit, online aggregation of core research in the biological, ecological, and environmental sciences. BioOne provides a sustainable online platform for over 170 journals and books published by nonprofit societies, associations, museums, institutions, and presses.

Your use of this PDF, the BioOne Web site, and all posted and associated content indicates your acceptance of BioOne's Terms of Use, available at www.bioone.org/page/terms_of_use.

Usage of BioOne content is strictly limited to personal, educational, and non-commercial use. Commercial inquiries or rights and permissions requests should be directed to the individual publisher as copy right holder. 


\title{
Ungulate browsing on European silver fir Abies alba: the role of occasions, food shortage and diet preferences
}

\begin{abstract}
Helene Häsler \& Josef Senn
European silver fir Abies alba is the most heavily browsed conifer in Central European mountain forests. Attempts to reduce ungulate browsing have often been unsuccessful, controversial or too costly. The aim of the work described here was to improve our understanding of the factors that lead to browsing on silver fir. The silver fir content in the diet of three sympatric ungulate species, chamois Rupicapra rupicapra, red deer Cervus elaphus and roe deer Capreolus capreolus, was determined by microhistological analysis of faeces collected at four sites in the Alps. Further, the supply of silver fir was assessed at the individual tree and patch scale and then extrapolated to site scale. Silver fir consumption was highest in winter, when diet composition varied among sites but not among ungulate species. Towards the summer, site-differences decreased and differences among ungulate species increased. Red and roe deer reduced consumption of silver fir, whereas chamois kept it constant. The use of silver fir was unrelated to the supply at the various sites, but increased with the proportion of trees growing amidst palatable herbaceous species. At the individual plant scale, ungulates browsed on the saplings with the larger needles. These results indicate that silver fir as food does not rank high among the available plant species, but is eaten opportunistically, especially when it grows close to more preferred food plants. However, when alternative food is scarce, particularly in winter, it may also represent a shortage food supply, and larger quantities are consumed. Yet, the fact that feeding on silver fir is mostly opportunistic may offer forest managers a way to approach the 'browsing problem'.
\end{abstract}

Key words: Abies alba, Capreolus capreolus, chamois, Cervus elaphus, diet selection, European silver fir, foraging behaviour, mountain forests, red deer, roe deer, Rupicapra rupicapra

Helene Häsler, Swiss Federal Institute for Forest, Snow and Landscape Research WSL, Zürcherstrasse 111, CH-8903 Birmensdorf, Switzerland, and Institute of Integrative Biology, ETH Zürich, Universitätstrasse 16, CH-8092 Zürich, Switzerland-e-mail: helene.haesler@alumni.ethz.ch

Josef Senn, Swiss Federal Institute for Forest, Snow and Landscape Research WSL, Zürcherstrasse 111, CH-8903 Birmensdorf, Switzerland - email: josef.senn@wsl.ch

Corresponding author: Helene Häsler

Received 4 February 2009, accepted 25 July 2011

Associate Editor: Iain Gordon

Wild ungulates make their foraging decisions at several spatial scales (Bergman et al. 2005). First, a feeding place is chosen, then a plant species, after that an individual plant and finally a particular plant part. In temperate mountain forests, this sequence of decisions often ends with the leader shoot of a young tree being browsed. In Central European mountain forests, European silver fir Abies alba is the most heavily browsed coniferous species, and the low regeneration success of this species in the recent past has often been attributed to the increasingly high numbers of ungulates (e.g. Motta 1996).

Because silver fir is an important species both economically and ecologically, poor survival of young trees is of major silvicultural concern (Senn \& Suter 2003). Attempts to reduce browsing have included protecting saplings with fences or repellents and culling ungulate populations. However, neither practice is satisfactory, since culling is controversial 
and a never-ending task, while fencing is costly, and repellents work only for a short time. We therefore aimed to improve the understanding of the browsing patterns of herbivores as a prerequisite for increasing the survival of young silver fir.

First, for three sympatric ungulate species at four sites in the Alps, we examined how the proportion of silver fir in the diet varied seasonally. The three species, chamois Rupicapra rupicapra, red deer Cervus elaphus and roe deer Capreolus capreolus, are all generalist herbivores, but while roe deer browse throughout the year, chamois and red deer largely graze in summer (Hofmann 1989, Homolka 1996). Evergreen conifers, and in particular the silver fir, have frequently been reported as winter food for all these ungulate species (i.e. shortage food; SaintAndrieux \& Klein 1999, Gebert \& Verheyden-Tixier 2001), and in contrast, the evergreen conifers are rarely eaten in summer when alternative food is abundant and diverse (but see Palmer \& Truscott 2003). Accordingly, food overlap is likely to be highest in winter and lowest in summer.

Another factor influencing the consumption of conifers is the type of habitat (Tixier \& Duncan 1996, Gebert \& Verheyden-Tixier 2001). Due to the fact that herbivores tend to consume a preferred plant species across different habitats in proportion to its local abundance, and providing that silver fir is a preferred food, we would expect the proportion of silver fir in the diet to be positively related to its availability in the respective habitat. Testing this prediction was our second aim.

While diet composition may indicate diet selection at the habitat scale, it may tell less about diet selection at the patch or individual scale. At the patch scale, the consumption of coniferous species can be more closely related both to physical factors, such as accessibility or aspect (Oswald \& Neuenschwander 1993, Heuzé et al. 2005), and to the abundance of neighbouring food plants. Palatable species in the neighbourhood often prove to increase the risk of being browsed (Mitchell \& McCowan 1986, Bergman et al. 2005, Smit et al. 2006), but may rarely also decrease it (Welch et al. 1991). Hence, thirdly, we were interested in how browsing on silver fir in mountain forests is influenced by the presence of alternative food plant species. If these neighbouring species are the prime target of ungulates, the risk of browsing at certain patches will increase, which will imply that silver fir is browsed incidentally.

The fourth aim was to evaluate diet selection at the scale of the individual tree. At this scale, selectivity may neither support nor refute a role of silver fir as occasional food, but would rather argue against a function as shortage food since ungulates apparently can afford to be selective. Because needle morphology can affect the browsing risk for Scots pine Pinus sylvestris (Danell et al. 1991) and Sitka spruce Picea sitchensis (Iason et al. 1996), we investigated whether this variable also affected the selection of silver fir.

In order to learn more about the role of silver fir as a food resource in mountain forests, we tested the following hypotheses: 1) silver fir consumption is generally highest in winter and differs between forest sites; silver fir consumption is generally lowest in summer, but varies among ungulate species. Roe deer, which is as a concentrate selector specialised on using high quality plant material, is expected to eat larger amounts of silver fir than the intermediate feeders red deer and chamois; 2) across sites, silver fir consumption positively correlates with silver fir supply. Within sites, browsing is more intensive on patches where there is alternative food. Among trees, ungulates choose those with the larger needles.

\section{Material and methods}

\section{Study sites}

Our study was performed in 2004 in four naturally regenerating mixed mountain forests located across the Central European Alps (Fig.1). Three sites, Visp $\left(46^{\circ} 17^{\prime} \mathrm{N}, 7^{\circ} 51^{\prime} \mathrm{E}\right)$, Escholzmatt $\left(46^{\circ} 55^{\prime} \mathrm{N}, 7^{\circ} 53^{\prime} \mathrm{E}\right)$ and Sarnen $\left(46^{\circ} 56^{\prime} \mathrm{N}, 8^{\circ} 13^{\prime} \mathrm{E}\right)$, were located in Switzerland, and one site, Triesenberg $\left(47^{\circ} 6^{\prime} \mathrm{N}\right.$, $9^{\circ} 33^{\prime} \mathrm{E}$ ), was in Liechtenstein. Our study areas ranged between 1,000 and 1,200 $\mathrm{m}$ a.s.1., were north- to westoriented and contained either spruce-fir (Norway spruce Picea abies and silver fir; Visp) or beechspruce-fir forests (European beech Fagus sylvatica, Norway spruce and silver fir; Escholzmatt, Sarnen and Triesenberg). The density of young silver fir differed markedly between sites, with approximately 6,000 saplings $(10-185 \mathrm{~cm}) / \mathrm{ha}$ at Visp, 2,000 at Escholzmatt, 600 at Sarnen and 750 at Triesenberg.

Chamois, red and roe deer were present at all sites. Local overall densities ranged between 18 and 25 ungulates $/ \mathrm{km}^{2}$ in 2004 (Brassel \& Brändli 1999, national hunting authorities, pers. comm.). Chamois was the most abundant species at Visp and Sarnen, roe deer at Escholzmatt, and roe deer shared dominance with red deer at Triesenberg. 


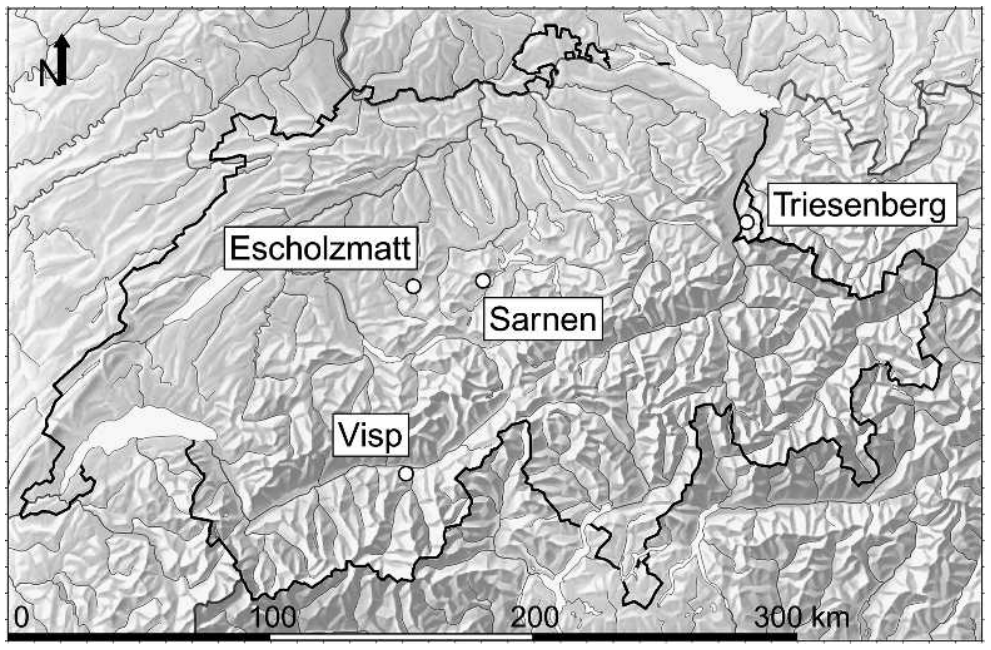

Figure 1. Locations of study sites in Switzerland (Visp, Escholzmatt, Sarnen) and Liechtenstein (Triesenberg). (C2008 swisstopo.

\section{Diet analysis}

To assess the diet of ungulates, we collected fresh faeces once per season at each study site. We did this on the route between the transects at each study site (see next section 'Estimation of silver fir supply'). Winter samples were collected in February, spring samples in May, summer samples in August and autumn samples in November. We aimed to get three samples per ungulate species per season per site, resulting in $3 \times 3 \times 4 \times 4=144$ samples, but only 132 samples were obtained. This was because some species were scarce or absent at particular sites at certain times of year.

Each sample consisted of five randomly selected pellets from a dung pile. The samples were stored frozen until use. For analysis, they were autoclaved, homogenised in a laboratory blender, washed through a $100-\mu \mathrm{m}$ sieve, and the residues transferred into $70 \%$ ethanol for sedimentation (Suter et al. 2004). Ten random grab samples of the sediment were then examined under the microscope, and the first 10 epidermal fragments to be found in each sample were recorded (resulting in 100 fragments/ sample). The fragments were classified into 'fir', 'spruce', 'unidentified conifer', 'Rubus', 'other species' (forbs, grasses, dwarf-shrubs, other trees, mosses and ferns) and 'unidentified' via comparison with a reference collection. Rubus was treated as a separate category because species of this genus (i.e. bramble $R$. fruticosus spp. and raspberry $R$. idaeus) are seasonally important food for wild ungulates (Homolka 1996, Storms et al. 2008), and the proportions of Rubus and silver fir consumption are found to vary inversely over the course of a year (Saint-Andrieux \& Klein 1999).

\section{Estimation of silver fir supply}

In summer 2003, young silver fir trees were surveyed along 10 strip transects of $50 \times 2 \mathrm{~m}$. These were randomly set out within an area of approximately 10 ha of closed forest at each of the four sites. The transects were at least $50 \mathrm{~m}$ apart and followed the contours.

On each transect, all silver fir saplings $\geq 10 \mathrm{~cm}$ were recorded and checked for browsed leader and lateral shoots from the previous year. Additionally, tree height, crown length, length of the longest lateral branch and stem position were recorded. Stem position was assessed using a three-point scale: 'central' if the stem was within the innermost third of the crown radius, 'intermediate' if it was within the middle third and 'peripheral' if it was within the outermost third of the crown radius (Fig. 2D-F). Further, crown contact with other trees and the presence of palatable herbaceous plants (grasses, forbs and Rubus) within a radius of $30 \mathrm{~cm}$ were recorded.

Because ungulates usually browse the tips of branches, browse supply per tree was treated as being proportional to a sapling's crown surface. This was estimated by treating the sapling as a cone with a height (h) and a fraction of the length of the longest lateral branch as the cone radius (r; see Fig. 2A-C). The fraction (b) depended on the stem position, being set to 1 if the stem was central, to $2 / 3$ if the stem was intermediate, and to $6 / 11$ if the stem was peripheral 
Figure 2. Diagrams showing the morphological measures used for the calculation of the crown surface area of silver fir. A-C) Lateral view: $h=$ crown length, $r=$ length of the longest lateral branch. Subscripts refer to central $\left(r_{c}\right)$, intermediate $\left(r_{i}\right)$ and peripheral $\left(r_{p}\right)$ stem position. D-F) Vertical projection view with the stem indicated by $\bullet$. Highlighted in grey are the fractions of the longest lateral branch used as crown radius.
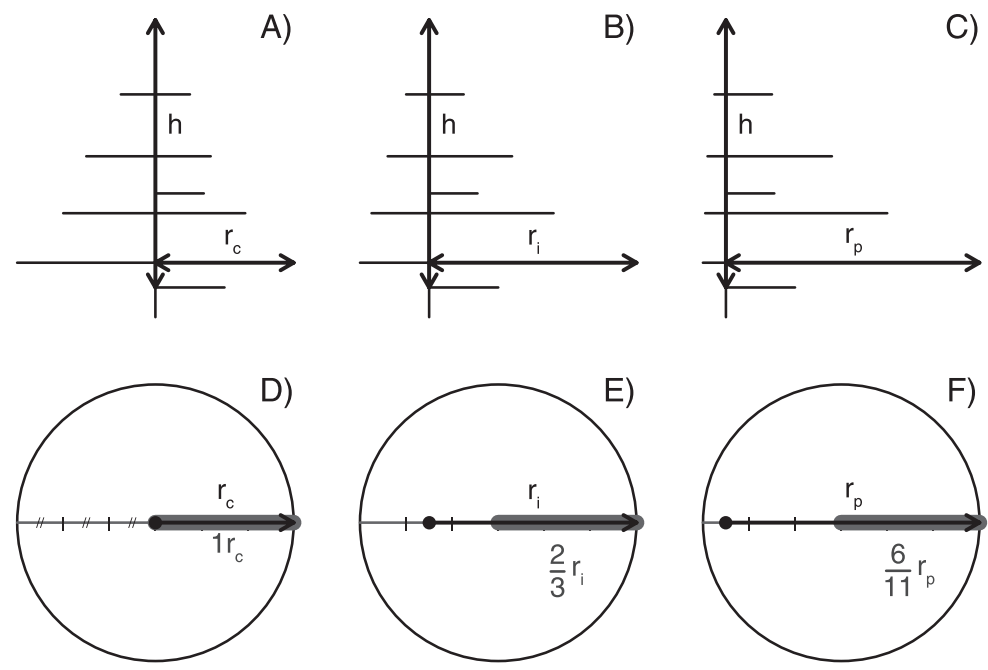

(see Fig. 2D-F). Accordingly, the conical crown surfaces (A) of silver fir saplings were calculated using the formula:

$$
\mathrm{A}=\pi \times \mathrm{br} \times \sqrt{(\mathrm{br})^{2}+\mathrm{h}^{2}} .
$$

Silver fir supply was hence equivalent to the total crown surface of all accessible young trees present at any one site. A tree was considered accessible to ungulates if it was not completely surrounded by other trees. Further, 10 needles from each tree's leader shoot ( $\mathrm{N}=600$ shoots) were collected, dried at $60^{\circ} \mathrm{C}$ for 48 hours, weighed to the nearest $0.0001 \mathrm{~g}$ and measured to an accuracy of $0.01 \mathrm{~mm}$.

\section{Statistical analysis}

Plant species composition in faecal pellets was first analysed with detrended correspondence analysis (DCA) to assess the origin of unidentified epidermal fragments. They accounted for $4.6-5.4 \%$ of an average faecal sample per site. As the category 'unidentified' was positioned exactly at the intersection point between the other diet categories and very close to the origin of the first two DCA axes, we discarded this category for further analyses and recalculated the remaining categories to total of $100 \%$. Correlations between food categories were tested using Spearman's rank correlation coefficient. Since the categories 'unidentified conifer' and 'fir' were highly correlated, we merged them, and because 'spruce' was found only rarely $(0.3-0.8 \%$ of an average sample/site), we merged it with 'other species'. Finally, three categories were left: 'fir', 'Rubus' and 'other species'. With these categories, we conducted multivariate analyses of variance (MAN-
OVA) to evaluate the significance of season, site and ungulate species for diet composition. Data were arcsine-square-root transformed prior to analysis.

Relationships between absolute consumption of silver fir browse (number of silver fir fragments in faeces) and silver fir supply, as well as between relative consumption of silver fir browse (number of silver fir fragments in faeces divided by silver fir supply) and percentage of silver fir saplings growing amidst palatable ground cover, were modelled using linear and log-linear regression, respectively.

Differences in needle weight and length between browsed and unbrowsed silver fir saplings were examined using t-tests and analysis of covariance (ANCOVA). Finally, it was cross-checked with a multilevel logistic regression including site as a random factor. All analyses were performed using $\mathrm{R}$ version 2.1.0 ( $\mathrm{R}$ Development Core Team 2005) with the multilevel logistic regression using the function glmmPQL (generalised linear mixed model with penalised quasi-likelihood estimation) in the MASS package (Venables \& Ripley 2002).

\section{Results}

\section{Effect of season, site and species on ungulate diet composition}

Average consumption of silver fir was highest in winter, when it accounted for $19 \%$ of total diet (Fig. 3). Consumption was higher at Visp and Triesenberg, with $28 \%$ and $30 \%$, respectively, while it was only $8 \%$ at Escholzmatt and $12 \%$ at Sarnen. Silver fir consumption by red and roe deer continuously decreased from winter to spring and summer to 

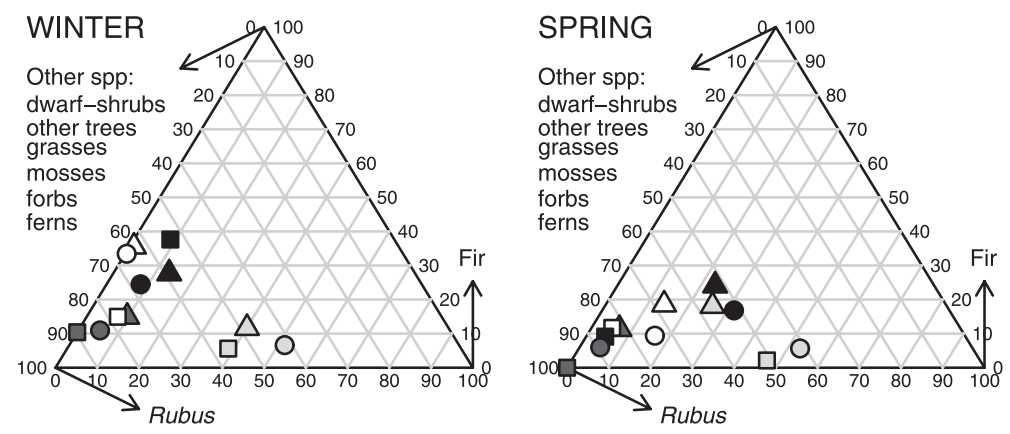

Figure 3. Diet composition of three ungulate species at four forest sites during the course of a year (mean percentages, $\mathrm{N}=132( \pm 3 /$ species/site/season)). Ungulate species (symbols): $\triangle$ chamois, $\square$ red deer and $\bigcirc$ roe deer. Study sites (fill colour): $\square$ Visp,

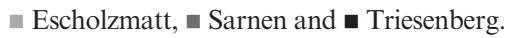
In winter, equally coloured symbols are close together (sites), in summer equal shapes (ungulate species). Spring and autumn are transitional stages.
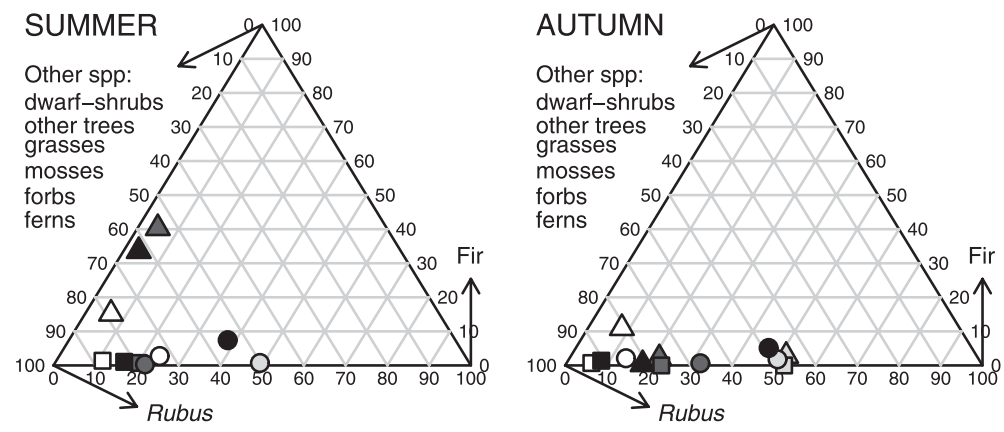

autumn, but in chamois it was highest in summer, reaching $>40 \%$ at Sarnen. In autumn, silver fir consumption by all ungulate species was negligible. Consumption of Rubus showed an inverse pattern, increasing from winter to spring and summer to autumn for red and roe deer, while in the case of chamois it was at a minimum in summer.

Study site was the only factor explaining a significant amount of the variance in the winter diet of chamois, red and roe deer (Table 1). However, with advancing season, differences among sites

Table 1. MANOVA of the arcsine-square-root transformed proportions of silver fir and Rubus spp. fragments in the seasonal diets of chamois, red and roe deer at four different study sites.

\begin{tabular}{llcrr}
\hline Model & \multicolumn{1}{c}{ Factors } & df & $\sim F$ & \multicolumn{1}{c}{$\mathrm{P}$} \\
\hline Winter diet & Site & 3 & 14.77 & $<0.001$ \\
$\mathrm{~N}=34$ & Ungulate species & 2 & 0.43 & 0.786 \\
& Site*ungulate species & 6 & 1.30 & 0.252 \\
Spring diet & Site & 3 & 4.16 & 0.003 \\
$\mathrm{~N}=32$ & Ungulate species & 2 & 3.93 & 0.009 \\
& Site*ungulate species & 6 & 0.64 & 0.796 \\
Summer diet & Site & 3 & 3.20 & 0.012 \\
$\mathrm{~N}=31$ & Ungulate species & 2 & 16.70 & $<0.001$ \\
& Site*ungulate species & 6 & 1.99 & 0.072 \\
Autumn diet & Site & 3 & 10.79 & $<0.001$ \\
$\mathrm{~N}=35$ & Ungulate species & 2 & 6.10 & $<0.001$ \\
& Site*ungulate species & 6 & 2.96 & 0.004 \\
\hline
\end{tabular}

(C) WILDLIFE BIOLOGY 18:1 (2012) decreased while differences among the ungulate species increased. In summer, species explained the highest proportion of variation in diet composition. In autumn, both site and ungulate species contributed equally and highly significantly to variation in diet composition and, in contrast to the other seasons, also the interaction between these two factors was significant.

\section{Consumption of silver fir in relation to fir and alternative forage supply}

With one exception, no silver fir trees $>185 \mathrm{~cm}$ tall showed any sign of recent leader or lateral shoot browsing. Considering only trees $\leq 185 \mathrm{~cm}$ in height, there was no significant correlation between use of silver fir and silver fir supply $(P=0.91)$, even in winter $(P=0.89)$. However, there were highly significant correlations between the relative use of silver fir and the proportion of trees surrounded by palatable herbaceous vegetation, both in winter $(\mathrm{P}<$ $0.001)$ and for all seasons combined $(\mathrm{P}<0.001)$.

\section{Selection of individual silver fir saplings}

In the comparison of browsed and unbrowsed needles on leader shoots, we only considered trees $\leq 110 \mathrm{~cm}$ tall, because the leaders of taller trees were not browsed. The needles of browsed leaders were significantly longer $(\mathrm{P}<0.001)$ and heavier 
$(\mathrm{P}<0.001)$ than those of unbrowsed leaders. They also had a significantly higher specific weight $(\mathrm{F}=$ 26.39, $\mathrm{P}<0.001$; tested as intercept in ANCOVA). Neither needle length nor weight was significantly related to the presence of palatable herbaceous vegetation around the tree $(\mathrm{P}=0.23$ and 0.15 , respectively).

\section{Discussion}

Our results show that the winter diet of chamois, red and roe deer reflects the food plants available on a site: diet composition of the three ungulate species was similar within sites but varied among sites. In summer, in contrast, diet composition of the three ungulate species differed, but for a particular species it was similar at all four study sites. But what role, exactly, does European silver fir play in this pattern of plant use?

\section{When is silver fir browsed?}

On average, silver fir use by ungulates was highest in winter, as has generally been found for coniferous species (Tixier \& Duncan 1996, Saint-Andrieux \& Klein 1999, Heuzé et al. 2005). This means that silver fir is eaten when other food is scarce. Furthermore, diet composition in winter differed between our study sites but not among the different ungulate species. At other times distinct trophic niches starting to overlap can be a sign of food shortage (Homolka 1996). These two observations suggest that silver fir is a shortage food, which may be promoted by the fact that sugar content of silver fir needles is likely to be highest in winter, as found in balsam fir Abies balsamea (Little 1970).

Towards summer, site-specific characteristics (i.e. botanical composition) gradually became less important and diet selection of ungulates turned species-specific. Red and roe deer reduced silver fir consumption and shifted to Rubus, whereas silver fir consumption by chamois increased slightly. Thus, in support of our first hypothesis, the three ungulate species differed most in their foraging behaviour when the vegetation was most abundant and diverse. Unexpectedly, silver fir was still prominent in the diet of chamois in summer, suggesting that for this species, fir is more than merely a shortage food. Indeed, it is even possible that silver fir consumption was promoted by the growth of other species.

The discrepancy in browsing behaviour between ungulate species may result from species-specific differences in the capacity to detoxify plant secondary compounds. Whereas roe deer as a concentrate selector is adapted to detoxify high levels of secondary compounds (Hofmann 1989, Hofmann et al. 2008), chamois as an intermediate feeder may be less able to do so. Unlike the larger red deer, chamois does not have sufficient capacity for prolonged intestinal retention of fibrous food (Robbins et al. 1995). To avoid high doses of plant secondary compounds in young tissue of concentrate foods (Rhoades \& Cates 1976), chamois may therefore switch to grazing in spring and summer. Additional browsing may contribute to a better utilisation of herbage by prolonging the retention time of grass in the rumen; presumably because of a physical entrapment of the grass particles in-between the less digestible browse particles. This increases the exposure time of grassy fibres to digestive enzymes (Baker $\&$ Hobbs 1987). Such an associative effect of silver fir browse on digestion efficiency may imply that silver fir is particularly at browsing risk where associated with grass. However, in autumn when nutritional quality of grass decreases, chamois may switch back to a diet based largely on forbs and Rubus as these species have in the meantime lost much of their toxicity (Rhoades \& Cates 1976).

\section{Where is silver fir browsed?}

Between sites, consumption of silver fir was not related to silver fir supply, which suggests that ungulates do not actively search for this species and, hence, that it is not a highly preferred food plant (see also Saint-Andrieux \& Klein 1999). However, there was a highly significant correlation between the proportion of silver fir saplings growing amidst palatable ground vegetation and the amount of silver fir being eaten. This indicates that once an ungulate decides to forage on a particular patch, silver fir, if present, is eaten too. The reasons could be physiological (e.g. if there is an associative effect of browse upon grass digestibility) or it could reflect the economical aspects of foraging (e.g. if it is less costly to switch to browsing on the same patch than to search for another patch with herbaceous vegetation). It could also have no adaptive significance, merely reflecting an opportunistic behaviour. Surrounding alternative food has often been found to increase the browsing probability for conifers (Mitchell \& McCowan 1986, Welch et al. 1991, Smit et al. 2005). This implies that lower-quality plant species suffer a higher risk of being browsed in the presence of higher-quality species, which conforms 
to the reverse of the repellent-plant hypothesis (Pfister \& Hay 1988). This hypothesis predicts that a plant should gain protection from herbivory when associated with a species of lower quality.

Whereas protection by inferior neighbours may work when foraging ungulates choose at the patch scale, it may not work when ungulates choose individual plants (Miller et al. 2007). The significantly larger needles on browsed as compared to unbrowsed leader shoots showed that when there was a choice between individual trees, ungulates preferred those with the larger needles. As neither needle length nor weight was related to the presence of herbaceous vegetation, the selection of trees with larger needles obviously was not a direct consequence of the feeding location but of individual plant selection, which calls into question the role of silver fir as a shortage food (MacArthur \& Pianka 1966). Needle size, indeed, was hypothesised to be the major correlate of needle palatability; at least for Scots pine (Löyttyniemi 1985, Edenius 1993) and Sitka spruce (Hartley et al. 1997). Larger needles mean more energy and nutrients per bite. In addition, needle size may also reflect some qualitative aspects of needle browse. In Sitka spruce, for example, maximum width of leader shoots, i.e. from needle tip to needle tip, was negatively related to the concentration of cellulose and lignin (Iason et al. 1996).

Since coniferous species, including European silver fir (Häsler et al. 2008), may react to browsing with enhanced needle growth (Löyttyniemi 1985, Duncan et al. 1998), the significantly larger needles on browsed as compared to unbrowsed trees in our study could be a logical result of ungulates eating mainly needles from previously browsed trees. Rebrowsing may be both a consequence of the herbivore-induced amelioration of needle quality and simply a consequence of revisiting previous feeding locations. Repeated browsing because of repeated visits fits the idea of occasional food.

\section{Why is silver fir browsed?}

Our results suggest that European silver fir is not a highly preferred diet for mountain ungulates, but is primarily an occasional food and secondarily a shortage food. Thus, in our study, browsing seemed focused on patches with herbaceous vegetation. This result is entirely consistent with observations made on individual silver fir saplings (Häsler 2008), showing that the browsing probability was significantly higher for trees surrounded by high-quality ground vegetation. The most promising approach to prevent browsing might therefore be to take advantage of the fact that feeding on silver fir is mostly opportunistic. Though alternative food may be the main reason for ungulate presence, it would be useful to strengthen research into ungulate habitat use in mountain forests to obtain a more detailed description of how and where 'occasions to browse' arise. This knowledge could then be implemented into forest management.

Acknowledgements - we would like to thank A. Ghiringhelli for his help with faecal sample preparation and U. Suter for identification of the plant epidermal fragments. Many thanks also to P.J. Edwards for his helpful contributions. Our study was supported by the Swiss National Science Foundation as part of the National Research Programme NRP 48 'Landscapes and Habitats of the Alps'.

\section{References}

Baker, D.L. \& Hobbs, N.T. 1987: Strategies of digestion: digestive efficiency and retention time of forage diets in montane ungulates. - Canadian Journal of Zoology 65: 1978-1984.

Bergman, M., Iason, G.R. \& Hester, A.J. 2005: Feeding patterns by roe deer and rabbits on pine, willow and birch in relation to spatial arrangement. - Oikos 109: 513-520.

Brassel, P. \& Brändli, U-B. 1999: Schweizerisches Landesforstinventar: Ergebnisse der Zweitaufnahme 19931995. - Paul Haupt, Bern, Switzerland, 442 pp. (In German).

Danell, K., Edenius, L. \& Lundberg, P. 1991: Herbivory and tree stand composition: moose patch use in winter. Ecology 72: 1350-1357.

Duncan, A.J., Hartley, S.E. \& Iason, G.R. 1998: The effect of previous browsing damage on the morphology and chemical composition of Sitka spruce (Picea sitchensis) saplings and on their subsequent susceptibility to browsing by red deer (Cervus elaphus). - Forest Ecology and Management 103: 57-67.

Edenius, L. 1993: Browsing by moose on Scots pine in relation to plant resource availability. - Ecology 74: 22612269.

Gebert, C. \& Verheyden-Tixier, H. 2001: Variations of diet composition of red deer (Cervus elaphus L.) in Europe. Mammal Review 31: 189-201.

Häsler, H. 2008: Impact of browsing by wild ungulates on growth and regeneration of European silver fir. - PhD thesis ETH No. 17911. ETH Zürich, Zürich, Switzerland, $113 \mathrm{pp}$

Häsler, H., Senn, J. \& Edwards, P.J. 2008: Light-dependent growth responses of young Abies alba to simulated ungulate browsing. - Functional Ecology 22: 48-57.

Hartley, S.E., Iason, G.R., Duncan, A.J. \& Hitchcock, D. 1997: Feeding behaviour of red deer (Cervus elaphus) offered Sitka spruce saplings (Picea sitchensis) grown 
under different light and nutrient regimes. - Functional Ecology 11: 348-357.

Heuzé, P., Schnitzler, A. \& Klein, F. 2005: Consequences of increased deer browsing winter on silver fir and spruce regeneration in the Southern Vosges mountains: Implications for forest management. - Annals of Forest Science 62: $175-181$

Hofmann, R.R. 1989: Evolutionary steps of ecophysiological adaptation and diversification of ruminants: a comparative view of their digestive system. - Oecologia 78: 443457.

Hofmann, R.R., Streich, J.W., Fickel, J., Hummel, J. \& Clauss, M. 2008: Convergent evolution in feeding types: salivary gland mass differences in wild ruminant species. Journal of Morphology 269: 240-257.

Homolka, M. 1996: Foraging strategy of large herbivores in forest habitats. - Folia Zoologica 45: 127-136.

Iason, G.R., Duncan, A.J., Hartley, S.E. \& Staines, B.W. 1996: Feeding behaviour of red deer (Cervus elaphus) on Sitka spruce (Picea sitchensis): the role of carbon-nutrient balance. - Forest Ecology and Management 88: 121-129.

Little, C.H.A. 1970: Seasonal changes in carbohydrate and moisture content in needles of balsam fir (Abies balsamea). - Canadian Journal of Botany 48: 2021-2028.

Löyttyniemi, K. 1985: On repeated browsing of Scots pine saplings by moose (Alces alces). - Silva Fennica 19: 387391.

MacArthur, R.H. \& Pianka, E. 1966: On optimal use of a patchy environment. - The American Naturalist 100: 603609.

Miller, A.M., McArthur, C. \& Smethurst, P.J. 2007: Effects of within-patch characteristics on the vulnerability of a plant to herbivory. - Oikos 116: 41-52.

Mitchell, B. \& McCowan, D. 1986: Patterns of damage in relation to the site preferences of deer in an enclosed plantation of Sitka spruce and lodgepole pine. - Scottish Forestry 40: 107-117.

Motta, R. 1996: Impact of wild ungulates on forest regeneration and tree composition of mountain forests in the Western Italian Alps. - Forest Ecology and Management 88: 93-98.

Oswald, B.P. \& Neuenschwander, L.F. 1993: Microsite variability and safe site description for western larch germination and establishment. - Bulletin of the Torrey Botanical Club 120: 148-156.

Palmer, S.C.F. \& Truscott, A.M. 2003: Seasonal habitat use and browsing by deer in Caledonian pinewoods. - Forest Ecology and Management 174: 149-166.

Pfister, C.A. \& Hay, M.E. 1988: Associational plant refuges: convergent patterns in marine and terrestrial communities result from differing mechanisms. - Oecologia 77: 118-129.
R Development Core Team 2005: R: A language and environment for statistical computing. - R Foundation for Statistical Computing, Vienna, Austria. Available at: http://www.r-project.org (Last accessed on 16 December 2011).

Rhoades, D.F. \& Cates, R.G. 1976: Toward a general theory of plant antiherbivore chemistry. - In: Wallace, J.W. \& Mansell, R.L. (Eds.); Biochemical interaction between plants and insects. Plenum Press, New York, New York, USA, pp. 168-213.

Robbins, C.T., Spalinger, D.E. \& van Hoven, W. 1995: Adaptation of ruminants to browse and grass diets: are anatomical-based browser-grazer interpretations valid? Oecologia 103: 208-213.

Saint-Andrieux, C. \& Klein, F. 1999: Roe and red deer diet in relation to damage to silver fir. - In: Duncan, P. \& Micol, T. (Eds.); Entretiens de Chizé en ecologie. Herbivore feeding strategies, population processes and impact on biodiversity. Centre d'Etudes Biologiques de Chizé, Bordeaux, France, pp. 409-422.

Senn, J. \& Suter, W. 2003: Ungulate browsing on silver fir (Abies alba) in the Swiss Alps: beliefs in search of supporting data. - Forest Ecology and Management 181: $151-164$

Smit, C., Béguin, D., Buttler, A. \& Müller-Schärer, H. 2005: Safe sites for tree regeneration in wooded pastures: a case of associational resistance? - Journal of Vegetation Science 16: 209-214.

Smit, C., den Ouden, J. \& Müller-Schärer, H. 2006: Unpalatable plants facilitate tree sapling survival in wooded pastures. - Journal of Applied Ecology 43: 305312

Storms, D., Aubry, P., Hamann, J-L., Saïd, S., Fritz, H., Saint-Andrieux, C. \& Klein, F. 2008: Seasonal variation in diet composition and similarity of sympatric red deer Cervus elaphus and roe deer Capreolus capreolus. - Wildlife Biology 14(2): 237-250.

Suter, W., Suter, U., Krüsi, B. \& Schütz, M. 2004: Spatial variation of summer diet of red deer Cervus elaphus in the eastern Swiss Alps. - Wildlife Biology 10(1): 43-50.

Tixier, H. \& Duncan, P. 1996: Are European roe deer browsers? A review of variations in the composition of their diets. - Revue d'Ecologie - la Terre et la Vie 51: 3-17.

Venables, W.N. \& Ripley, B.D. 2002: Modern Applied Statistics with S. - Springer, New York, New York, USA, 495 pp.

Welch, D., Staines, B.W., Scott, D., French, D.D. \& Catt, D.C. 1991: Leader browsing by red and roe deer on young Sitka spruce trees in western Scotland. I. Damage rates and the influence of habitat factors. - Forestry 64: 61-82. 